\title{
TINJAUAN PERSPEKTIF BALANCED SCORE CARD (BSC) ATAS KINERJA BANK SYARIAH
}

\author{
Putu Widhi Iswari
}

\begin{abstract}
Abstrak
Partisipasi dan penawaran produk dan layanan berbasis syariah tidak hanya dilakukan oleh perbankan syariah saja, melainkan juga diikuti oleh perbankan konvensional. Dua kubu tersebut tentu saja berbeda dalam beberapa hal prinsip. Hal ini kemudian menjadi tantangan bagi pelaku perbankan syariah untuk terus meningkatkan proses operasional, selain juga melakukan pengembangan produk syariah sehingga dapat bersaing dalam tataran global. Kinerja sangat erat hubungannya dengan sejauh mana bisnis proses yang efektif dan efisien dijalankan oleh semua elemen organisasi yang terlibat dalam perbankan syariah. Bisnis Proses berkaitan erat dengan tujuan bisnis dari sebuah organisasi. Tulisan ini dirancang untung mengkaji hal tersebut.
\end{abstract}

Kata Kunci: Bank Syariah, Perspektif Balanced Score Card, Kinerja

\section{A. Pendahuluan}

Perbankan syariah sebagai suatu organisasi publik, yang bertanggungjawab memberikan kepuasan kepada seluruh stakeholder dan dituntut mampu untuk memberikan pelayanan yang transparan dan akuntabel. Oleh karena itu, peningkatan yang signifikan dari kinerja seluruh lembaga perbankan syariah yang ada menuntut untuk segera dilakukan.

BSC dengan 4 perspektif yang di dalamnya terdiri dari; Financial (Keuangan), Customer (Pelanggan), Internal Business Process (Bisnis Proses) dan Learning \& Growth (Proses Pertumbuhan dan Pembelajaran) dapat digunakan sebagai alat ukur untuk melakukan evaluasi dan kontrol, yang akan meningkatkan keseluruhan proses dalam pelayanan kepada seluruh stakeholder dan proses pengelolaan perbankan syariah. Bank sebagai organisasi yang 
menjalankan proses-proses bersifat konstan, dapat dikembangkan dengan perbaikan kinerja secara terus menerus.

Pada dasarnya, aktifitas manusia apapun bentuk dan ragamnya- dikatakan ideal jika sesuai dengan apa yang Rasulullah saw. contohkan. Dalam hal ini, setidaknya beberapa sifat yang patut ditiru, pertama; fathanah yang berarti cerdas, pandai, dan cerdik. Tanpa sifat yang satu ini, mustahil kita -manusiadapat bermuamalah. Untuk melakukan pembelajaran dan pertumbuhan misalnya, diperlukan kecerdasan mental dan fisik sehingga training, improvement, serta peningkatan kualitas SDM akan tercapai. Kedua; amanah. Sifat ini bermakna dapat dipercaya. Selain yang pertama, sifat yang kedua ini mutlak wajib ada dalam setiap aktifitas yang dilakukan. Tidak saja terkait dengan kualitas kinerja seseorang, melainkan pasti erat hubungannya dengan tingkat kepuasan pelanggan dan pengelolaan keuangan. Mustahil tercapai jika amanah tidak dilakukan dengan sebaik-baiknya. Ketiga; siddiq, yaitu sikap jujur. Masih sejalan dengan amanah, maka jujur lebih menekankan pada aspek batiniyah seseorang. Seseorang yang jujur pasti amanah. Proses pembelajaran dan pertumbuhan ini bersumber dari faktor-faktor sumber daya manusia, sistem, dan prosedur organisasi, termasuk dalam perspektif ini adalah pelatihan dan budaya perusahaan yang berhubungan dengan perbaikan individu dan organisasi.

Hal di atas berhubungan dengan pelaksanaan suatu sistem yang konsisten sehingga akan melahirkan sebuah tatanan yang rapih dan menghasilkan yang lebih dari yang dikerjakan. Firman Allah surat An-Nahl ayat 97. "Barangsiapa yang mengerjakan amal saleh, baik laki-laki maupun perempuan dalam keadaan beriman, Maka Sesungguhnya akan kami berikan kepadanya kehidupan yang baik dan Sesungguhnya akan kami beri balasan kepada mereka dengan pahala yang lebih baik dari apa yang telah mereka kerjakan.

Kata shalih dapat dipahami dalam arti baik, serasi atau bermanfaat dan tidak rusak. Seseorang dinilai beramal saleh, apabila ia dapat memelihara nilainilai sesuatu. Sehingga kondisinya tetap tidak berubah sebagaimana adanya, dan dengan demikian sesuatu itu tetap berfungsi dengan baik dan bermanfaat.

Dalam melakukan pengembangan kebijakan untuk memenuhi permasalahan dan juga mengenai isu market share atas perbankan syariah yang masih rendah, dibutuhkan adanya pertimbangan yang mencakup elemenelemen yang berpengaruh baik langsung maupun tidak langsung terhadap pemenuhan target operasional yang ingin dicapai. Perencanaan yang komprehensif dan terintegrasi merupakan hal yang kompleks. Pikiran manusia 
atau 'mental model' tidak dapat mencukupi untuk memperhitungkan semua elemen-elemen yang terlibat dan secara konsisten dengan terus memerhatikan interaksi-interaksi yang ada di antara elemen-elemen tersebut.

Perencanaan seperti ini membutuhkan suatu alat bantu yang dapat menolong pembuat keputusan untuk melakukan pertimbangan atas luasnya cakupan dari perbankan syariah yang terdiri dari faktor-faktor yang saling berkaitan dan juga dalam membantu para stakeholder dalam membagi dan mendiskusikan pengetahuan dan pengalaman operasi yang dimilikinya terhadap sistem yang ada dengan stakeholder lainnya yang terkait.

Berdasarkan hal di atas, nantinya akan menghasilkan sebuah model yang dapat mensimulasikan kinerja bank syariah berdasarkan perspektif balanced score card untuk memperoleh kebijakan yang dapat diterapkan dalam pencapaian sasaran yang ada. Sementara itu, hasil yang diperoleh dari model tersebut, akan dikembangkan kebijakan terbaik dalam meraih peningkatan kinerja bank syariah sesuai dengan kondisi skenario yang berlaku.

\section{B. Tinjauan Teoritis}

\section{Bank Syariah}

Syariah adalah kata bahasa Arab untuk hukum Islam, juga dikenal sebagai Hukum Allah. Istilah Syariah sendiri berasal dari kata kerja Shara'a. Ada empat sumber Syari'at dalam Islam (Hafij Ullah 2014), yaitu:

Interpretasi dari Alqur'an yaitu wahyu Allah kepada Nabi Muhammad selama masa Kenabiannya sekitar 23 tahun;

* Interpretasi dari Hadis, sumber penting dari agama Islam dan pada dasarnya mengacu pada Nabi Muhammad;

* Ijma, konsensus para ulama (Konsensusdari para ahli hukum pada setiap masalah fikih setelah tidak adanya Nabi Muhammad/penalaran secara kolektif;

- Qiyas/Ijtihad (penalaran oleh salah satu/seorang individu )

Bank syariah melakukan kegiatan mereka sesuai dengan pedoman syariat Islam dengan tidak melakukan pemberian bunga/riba. Pada dasarnya, syariat adalah prinsip utama membimbing untuk mengarahkan semua operasional di dalam bank syariah (Siddiqi, 1983; Ahmad, 1984; Siddiqi, 1985; Khan dan Mirakhor, 1986; Ahmad, 2000; Siddiqui, 2001).

Penelitian yang telah dilakukan oleh Jalil dan Rahman (2010) juga mencatat bahwa kekejaman dan ketidakadilan dalam sistem keuangan karena riba harus dihapuskan dan pembangunan sosial ekonomi kemasyarakatan umat harus 
dipastikan dengan memperkenalkan cara-cara atau metode yang bersifat halal dalam berbisnis misalnya musharakah, mudharabah, bai' salam dan ijarah.

Perkembangan perbankan syariah di Indonesia yang semakin berkembang dengan adanya bank konvensional yang juga berpartisipasi dan menawarkan produk dan layanan perbankan berdasarkan prinsip-prinsip Islam, maka menjadi penting bagi pelaku perbankan syariah untuk terus meningkatkan proses operasional dan juga melakukan pengembangan produk-produk syariah agar dapat terus bersaing dalam perekonomian global.

\section{Kinerja}

Kinerja perbankan syariah yang baik akan menghasilkan kegiatan seluruh elemen terkait dalam melaksanakan tugas dan tanggung jawab masing-masing dalam rangka mencapai tujuan organisasi, yang terdiri dari: definisi kinerja, melakukan pengukuran atas kinerja yang sudah dijalankan dan melakukan umpan balik (feed back) atas kinerja yang telah dilakukan sebelumnya sebagai bentuk evaluasi untuk selanjutnya Noe (2000). Pertama, Kinerja sebagai bentuk pencapaian dalam peningkatan bisnis proses dalam sebuah organisasi, yaitu mencakup kinerja keuangan dan kinerja non keuangan/sosial. Kedua, Kinerja tersebut harus dibuat sebuah pengukuran yang komprehensif sehingga dijadikan alat untuk memonitoring kinerja semua elemen yang terlibat dalam organisasi. Ketiga, Adanya umpan balik/feed back setelah dilakukan pengukuran atas kinerja sehingga tujuan oragnisasi dapat tercapai dengan baik. Performance atau kinerja merupakan hasil atau keluaran dari suatu proses (Nurlaila, 2010:71).

Menurut pendekatan perilaku dalam manajemen, kinerja adalah kuantitas atau kualitas sesuatu yang dihasilkan atau jasa yang diberikan oleh seseorang yang melakukan pekerjaan (Luthans, 2005:165). Kinerja merupakan prestasi kerja, yaitu perbandingan antara hasil kerja dengan standar yang ditetapkan (Dessler, 2000:41). Semua elemen yang terlibat dalam organisasi, dalam hal ini adalah perbankan syariah harus menyadari bahwa kinerja maksimal akan membuat tercapainya tujuan keuangan maupun tujuan non keuangan.

Kinerja adalah hasil kerja baik secara kualitas maupun kuantitas yang dicapai oleh seseorang dalam melaksanakan tugas sesuai tanggung jawab yang diberikan (Mangkunagara, 2002:22). Informasi mengenai semua faktor yang terkait mutlak dibutuhkan agar pihak manajerial dapat melakukan pengambilan keputusan untuk organisasi Daft and Macintosh (1978).

Kinerja sangat erat hubungannya dengan sejauh mana bisnis proses yang efektif dan efisien dijalankan oleh semua elemen organisasi yang terlibat dalam 
perbankan syariah. Bisnis Proses adalah organisasi dari semua orang, material/bahan baku, sumber energi yang digunakan dan sekumpulan prosedur yang digunakan sebagai pedoman atau acuan kegiatan kerja untuk mencapai tujuan bisnis dari organisasi yang bersangkutan.

Kinerja dari sudut pandang syariah Menurut Mursi (1997) dalam Wibisono (2002), adalah suatu pencapaian yang diperoleh seseorang atau organisasi dalam bekerja/berusaha yang mengikuti kaidah-kaidah agama atau prinsip-prinsip ekonomi Islam. Terdapat beberapa dimensi kinerja Islami meliputi:

1. Amanah dalam bekerja yang terdiri atas: profesional, jujur, ibadah dan amal perbuatan; dan

2. Mendalami agama dan profesi terdiri atas: memahami tata nilai agama, dan tekun bekerja.

Indikator kinerja adalah ukuran kuantitatif dan/atau kualitatif yang menggambarkan tingkat pencapaian suatu sasaran atau tujuan kegiatan/ usaha yang telah ditetapkan. Menurut Zadjuli (2006b), Islam mempunyai beberapa unsur dalam melakukan penilaian kinerja suatu kegiatan/usaha yang meliputi:

- Niat bekerja karena Allah,

- Dalam bekerja harus memberikan kaidah/norma/syariah secara totalitas,

- Motivasi bekerja adalah mencari keberuntungan di dunia dan akherat,

- Dalam bekerja dituntut penerapan azas efisiensi dan manfaat dengan tetap menjaga kelestarian lingkungan,

- Mencari keseimbangan antara harta dengan ibadah, dan setelah berhasil dalam bekerja hendaklah bersyukur kepada Allah SWT.

Dalam unsur penilaian kinerja tersebut, orang yang berkerja adalah mereka yang menyumbangkan jiwa dan tenaganya untuk kebaikan diri, keluarga, masyarakat dan negara tanpa menyusahkan orang lain.

Oleh karena itu, kategori "ahli surga" seperti yang digambarkan dalam Alqur'an bukanlah orang yang mempunyai pekerjaan/jabatan yang tinggi dalam suatu perusahaan/instansi sebagai manajer, direktur, teknisi dalam suatu bengkel dan sebagainya. Tetapi sebaliknya Alqur'an menggariskan golongan yang baik lagi beruntung (al-falah) itu adalah orang yang banyak takwa kepada Allah, khusyu salatnya, baik tutur katanya, memelihara pandangan dan kemaluannya serta menunaikan tanggung jawab sosialnya seperti mengeluarkan zakat dan lainnya. Golongan ini mungkin terdiri dari pegawai, supir, tukang sapu ataupun seorang yang tidak mempunyai pekerjaan tetap. Sifat-sifat di ataslah sebenarnya yang menjamin kebaikan dan kedudukan seseorang di dunia dan di akhirat kelak. 
Jika membaca hadis-hadis Rasulullah saw. tentang ciri-ciri manusia yang baik di sisi Allah, maka tidak heran bahwa di antara mereka itu ada golongan yang memberi minum anjing kelaparan, mereka yang memelihara mata, telinga dan lidah dari perkara yang tidak berguna, tanpa melakukan amalan sunnah yang banyak dan seumpamanya.

Dalam Islam, kemuliaan seorang manusia itu bergantung kepada apa yang dilakukannya. Oleh karena itu suatu pekerjaan yang mendekatkan seseorang kepada Allah adalah sangat penting serta patut untuk diberi perhatian dan reward yang setimpal. Oleh karena itu dalam hadis Rasulullah disebutkan: "Barang siapa pada malam hari merasakan kelelahan karena bekerja pada siang hari, maka pada malam itu ia diampuni Allah.” (HR. Ahmad \& Ibnu Asakir)

Menurut Asyraf A. Rahman (dalam Khayatun, 2008), istilah "kerja" dalam Islam bukanlah semata-mata merujuk kepada mencari rezeki untuk menghidupi diri dan keluarga dengan menghabiskan waktu siang maupun malam, dari pagi hingga sore, terus menerus tak kenal lelah, tetapi kerja mencakup segala bentuk amalan atau pekerjaan yang mempunyai unsur kebaikan dan keberkahan bagi diri, keluarga dan masyarakat sekelilingnya serta negara.

Di antara hadis yang menjelaskan tentang kerja dalam Islam, sebagaimana berikut: Dari Abu Abdullah Az-Zubair bin Al-'Awwam r.a., ia berkata: Rasulullah saw bersabda: "Sungguh seandainya salah seorang di antara kalian mengambil beberapa utas tali, kemudian pergi ke gunung dan kembali dengan memikul seikat kayu bakar dan menjualnya, kemudian dengan hasil itu Allah mencukupkan kebutuhan hidupmu, itu lebih baik daripada meminta-minta kepada sesama manusia, baik mereka memberi ataupun tidak." (HR. Bukhari)

Dalam hadis-hadis yang disebutkan di atas, menunjukkan bahwa bekerja merupakan perbuatan yang sangat mulia dalam ajaran Islam. Rasulullah saw memberikan pelajaran menarik tentang pentingnya bekerja. Dalam Islam bekerja bukan sekadar memenuhi kebutuhan perut, tapi juga untuk memelihara harga diri dan martabat kemanusiaan yang seharusnya dijunjung tinggi. Karenanya, bekerja dalam Islam menempati posisi yang teramat mulia bahkan dikategorikan jihad fisabilillah.

Dengan demikian Islam memberikan apresiasi yang sangat tinggi bagi mereka yang mau berusaha dengan sekuat tenaga dalam mencari nafkah (penghasilan). Sebagaimana riwayat: "Rasulullah saw pernah ditanya, Pekerjaan apakah yang paling baik? Beliau menjawab, Pekerjaan terbaik 
adalah usaha seseorang dengan tangannya sendiri dan seтиa perjual belian yang dianggap baik." (HR. Ahmad dan Baihaqi).

Kerja juga berkait dengan martabat manusia. Seorang yang telah bekerja dan bersungguh-sungguh dalam pekerjaannya akan bertambah martabat dan kemuliannya, karena bekerja merupakan kewajiban. Menurut Syamsudin (dalam Heriyanto, 2008), Seorang pekerja atau pengusaha muslim dalam melakukan berbagai aktivitas usaha harus selalu bersandar dan berpegang teguh pada dasar dan prinsip berikut ini: Seorang muslim harus bekerja dengan niat yang ikhlas karena Allah SWT. Karena dalam kacamata syariat, bekerja hanyalah untuk menegakkan ibadah kepada Allah SWT agar terhindar dari halhal yang diharamkan dan dalam rangka memelihara diri dari sifat-sifat yang tidak baik, seperti meminta-minta atau menjadi beban orang lain. Rasulullah SAW bersabda: "Binasalah orang- orang Islam kecuali mereka yang berilmu. Maka binasalah golongan berilmu, kecuali mereka yang beramal dengan ilmu mereka. Dan binasalah golongan yang beramal dengan ilmu mereka kecuali mereka yang ikhlas. Sesungguhnya golongan yang ikhlas ini juga masih dalam keadaan bahaya yang amat besar ......". Bekerja juga bisa menjadi sarana untuk berbuat baik kepada orang lain dengan cara ikut andil membangun umat di masa sekarang dan masa yang akan datang, serta melepaskan umat dari belenggu ketergantungan kepada umat lain dan jeratan transaksi haram.

Seorang muslim dalam usaha harus berhias diri dengan akhlak mulia, seperti: sikap jujur, amanah, menepati janji, menunaikan hutang dan membayar hutang dengan baik, memberi kelonggaran orang yang sedang mengalami kesulitan membayar hutang, menghindari sikap menangguhkan pembayaran hutang, tamak, menipu, kolusi, melakukan pungli (pungutan liar), menyuap dan memanipulasi atau yang sejenisnya. Seorang muslim harus bekerja dalam halhal yang baik dan usaha yang halal. Sehingga dalam pandangan seorang pekerja dan pengusaha muslim, tidak akan sama antara proyek dunia dengan proyek akhirat. "Dari Miqdan r.a. dari Nabi Muhammad Saw, bersabda: Tidaklah makan seseorang lebih baik dari hasil usahanya sendiri. Sesungguhnya Nabi Daud a.s., makan dari hasil usahanya sendiri." (HR. Bukhari)

Baginya tidak akan sama antara yang baik dan yang buruk atau antara yang halal dan haram, meskipun hal yang buruk itu menarik hati dan menggiurkan karena besarnya keuntungan materi yang didapat. Ia akan selalu menghalalkan yang halal dan mengharamkan yang haram, bahkan hanya berusaha mencari rizki sebatas yang dibolehkan oleh Allah SWT dan Rasul-Nya. 
Seorang muslim dalam bekerja harus menunaikan hak-hak yang harus ditunaikan, baik yang terkait dengan hak-hak Allah SWT (seperti zakat) atau yang terkait dengan hak-hak manusia (seperti memenuhi pembayaran hutang atau memelihara perjanjian usaha dan sejenisnya). Karena menunda pembayaran hutang bagi orang yang mampu merupakan suatu bentuk kedzaliman. Menyia-nyiakan amanah dan melanggar perjanjian bukanlah akhlak seorang muslim, hal itu merupakan kebiasaan orangorang munafik.

Seorang muslim harus menghindari transaksi riba atau berbagai bentuk usaha haram lainnya yang menggiring ke arahnya. Karena dosa riba sangat berat dan harta riba tidak berkah, bahkan hanya akan mendatangkan kutukan dari Allah SWT dan Rasul-Nya, baik di dunia maupun akherat.

Seorang pekerja muslim tidak memakan harta orang lain dengan cara haram dan bathil, karena kehormatan harta seseorang seperti kehormatan darahnya. Harta seorang muslim haram untuk diambil kecuali dengan kerelaan hatinya dan adanya sebab syar'i untuk mengambilnya, seperti upah kerja, laba usaha, jual beli, hibbah, warisan, hadiah dan yang semisalnya.

Seorang pengusaha atau pekerja muslim harus menghindari segala bentuk sikap maupun tindakan yang bisa merugikan orang lain. Ia juga harus bisa menjadi mitra yang handal sekaligus kompetitor yang bermoral, yang selalu mengedepankan kaidah "Segala bahaya dan yang membahayakan adalah haram hukumnya".

Seorang pengusaha dan pekerja muslim harus berpegang teguh pada aturan syari'at dan bimbingan Islam agar terhindar dari pelanggaran dan penyimpangan yang mendatangkan saksi hukum dan cacat moral. Dan hal ini dapat dilihat dari niat pekerja tersebut, sebagaimana hadis Rasulullah yang diriwayatkan oleh Umar r.a., berbunyi: "Bahwa setiap amal itu bergantung pada niat, dan setiap individu itu dihitung berdasarkan apa yang diniatkannya ..." Seorang muslim dalam bekerja dan berusaha harus bersikap loyal kepada kaum mukminin dan menjadikan ukhuwahdi atas kepentingan bisnis, sehingga bisnis tidak menjadi sarana untuk menciptakan ketegangan dan permusuhan sesama kaum muslimin. Dan ketika berbisnis jangan berbicara sosial, sementara ketika bersosial jangan berbicara bisnis, karena berakibat munculnya sikap tidak ikhlas dalam beramal dan berinfak.

\section{Balanced Score Card}

Kaplan dan Norton (1996) menyatakan bahwa BSC dapat digunakan untuk memperjelas dan mendapatkan pemahaman menyeluruh tentang strategi; 
berkomunikasi dari seluruh organisasi; menyelaraskan tujuan departemen dan pribadi dengan strategi; menghubungkan tujuan strategis dengan target jangka panjang dan anggaran tahunan; mengidentifikasi dan menyelaraskan inisiatif strategis; melakukan tinjauan strategis periodik dan sistematis; dan mendapatkan umpan balik untuk mempelajari dan meningkatkan strategi bisnis. BSC menyediakan struktur yang komprehensif dan koheren untuk memahami bisnis dan adanya hubungan timbal balik yang membutuhkan proses pengambilan keputusan dan/atau pemecahan masalah.

Balanced Scorecard (BSC) adalah teknik untuk menerjemahkan strategi organisasi ke dalam istilah yang dapat dipahami, dikomunikasikan dan ditindaklanjuti menggunakan bahasa pengukuran untuk lebih jelas mendefinisikan arti dari konsep strategis seperti faktor yang terkait dengan kuantitas dan kualitas, kepuasan pelanggan dan pertumbuhan yang secara akurat menggambarkan strategi untuk dilakukan pengembangan, kemudian berfungsi sebagai kerangka kerja untuk sistem manajemen.

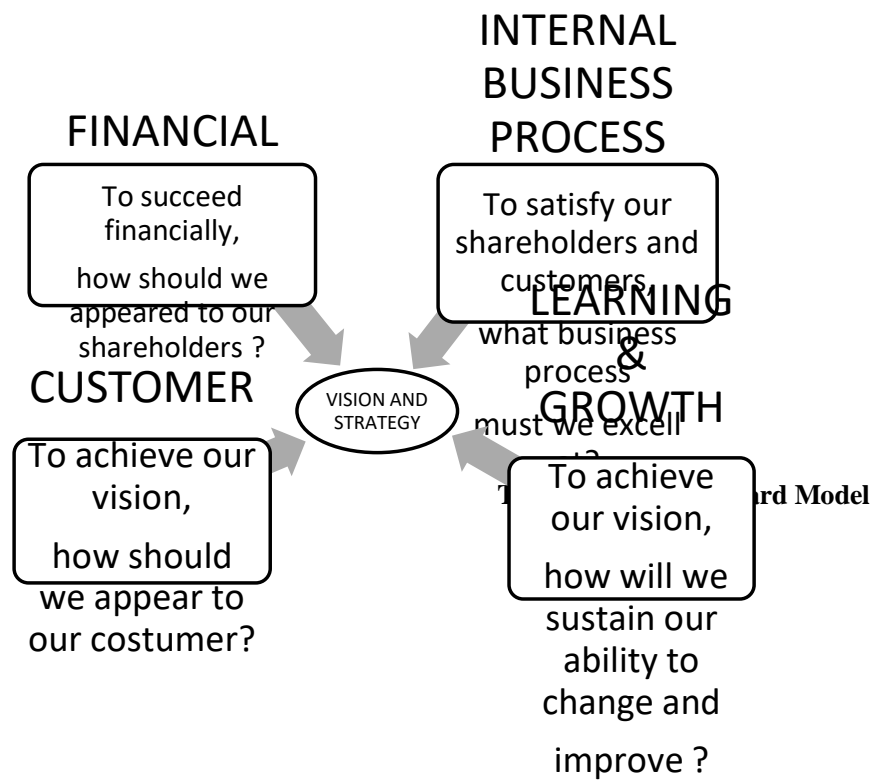

Hal ini memberikan pandangan dari kinerja organisasi dari empat perspektif:

1. Keuangan - strategi untuk pertumbuhan, profitabilitas dan risiko bisnis dilihat dari perspektif shareholder

2. Pelanggan - strategi untuk menciptakan nilai dan diferensiasi dari perspektif pelanggan 
3. Proses Bisnis Internal - prioritas strategis untuk berbagai proses bisnis yang membuat pelanggan dan pemegang saham mencapai kepuasan dalam tingkat tertentu

4. Pembelajaran dan Pertumbuhan - prioritas untuk menciptakan iklim yang mendukung perubahan organisasi, inovasi dan pertumbuhan.

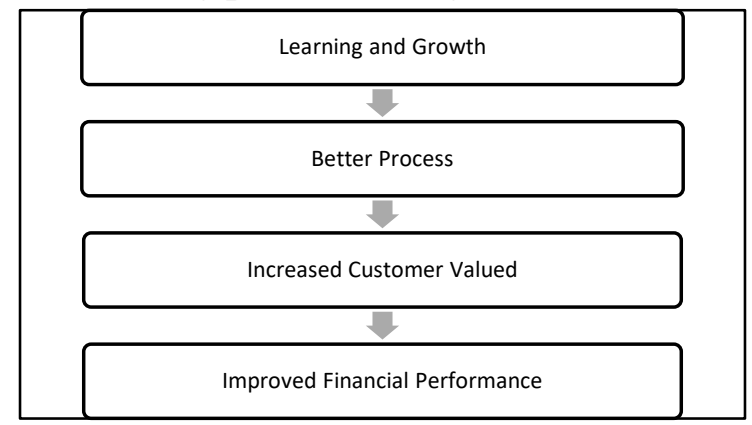

The Cause and Effect Relationships among the Perspectives

\section{Pembahasan}

Perspektif Balanced Score Card dapat secara teknis dan aplikatif memetakan aspek finansial dan aspek non finansial/sosial yang ada di dalam perbankan syariah, di antaranya adalah:

\section{a. Perspektif Pelanggan (Customer)}

Pandangan kepada pelanggan dari segi Islam/Syariah. Kepuasan pelanggan erat kaitannya dengan kualitas kinerja, sehingga dengan kinerja yang baik dipastikan pelanggan juga akan merasakan kepuasan. Pada perspektif ini, pelanggan (customer) merupakan hal yang harus diperhitungkan, karna masyarakat sebagai pelanggan yang menikmati produk dan pelayanan dari Perbankan Syariah, bagaimana masyarakat umum memahami dan pada akhirnya mau untuk memindahkan semua transaksi keuangannya; baik transaksi yang berhubungan dengan penyimpanan dalam bentuk tabungan/deposito maupun transaksi yang berhubungan dengan proses pembiayaan keuangan ke dalam Bank Syariah, hal-hal yang terkait dengan hal ini adalah:

Ukuran Pangsa Pasar/Market Share dari Bank Syariah

Aspek Segmenting, Targeting dan Positioning dari proses bisnis bank syariah tersebut

Tingkat Penarikan atas pelanggan baru/nasabah baru

Tingkat Penarikan kembali atas pelanggan lama/nasabah lama yang telah meninggalkan/menutup segala transaksinya di bank syariah tersebut 
Pertumbuhan bisnis atau keuangan/pengembangan dari pelanggan lama

Kepuasan pelanggan atas fasilitas, karyawan, sarana dan prasarana utamapendukung dari bank syariah

Kepuasan pelanggan atas produk-produk simpanan atau pembiayaan dan penjelasan terkait perbankan syariah

Kekuatan WOM (word of mouth) dalam meningkatkan market share bank syariah

\section{b. Perspektif Keuangan (Finance)}

Pandangan hal menyangkut keuangan dari segi Islam/Syariah keuangan Islam berfungsi sebagai:

1. Penghapusan bunga dari semua transaksi keuangan dan pembaharuan semua aktivitas keuangan dan perbankan agar sesuai dengan prinsip Islam. Hal ini jelas tertuang dalam Alquran, bahwa Allah memerintahkan perniagaan dan dalam waktu yang sama Allah juga melarang praktik riba.

2. Pencapaian distribusi pendapatan dan kekayaan yang wajar, hal ini dapat dilihat dari larangan menimbun harta serta perintah menunaikan zakat, baik fitrah maupun zakat yang lain.

Dapat dikatakan bahwa ketika sistem keuangan telah sesuai dengan minimal- dua prinsip tersebut maka itu sesuai dengan ajaran Islam. Keuangan sebagai komponen penting dalam sebuah proses bisnis, untuk perbankan syariah ini berarti berhubungan dengan efisiensi biaya, proses pembiayaan, performa biaya, di antaranya adalah:

Non Performing Loans, yaitu untuk melihat hasil perbandingan antara total pembiayaan yang bermasalah dengan total pembiayaan yang telah dikeluarkan dalam rentang waktu tertentu

Efisiensi BO/PO, yaitu untuk melihat hasil perbandingan antara total beban penunjang kegiatan operasional dari bank syariah dengan nilai pendapatan/income yang diperoleh oleh ban syariah tersebut dalam rentang waktu tertentu

* Loan to Deposit Ratios, yaitu untuk melihat total kredit yang telah diberikan oleh bank syariah dengan total dana yang dihimpun dari pihak ketiga dalam rentang waktu tertentu

\section{c. Perspektif Bisnis Proses (Business Process)}


Pandangan hal menyangkut bisnis proses dari segi Islam/Syariah adalah proses ekonomi yang tidak lain diarahkan untuk mencapai kesejahteraan manusia dalam kehidupannya, juga tidak terlepas dari konteks pengertian ibadah secara luas tersebut. Inti dari kelangsungan hidup manusia terletak pada sejauh mana ia melakukan aktivitas untuk mempertahankan hidupnya. Dengan demikian, kegiatan ekonomi merupakan bagian integral dari muamalah (ibadah) dengan segala dimensinya. Bisnis merupakan salah satu ibadah yang telah diterapkan oleh Nabi Muhammad saw. Bisnis juga merupakan format yang baik untuk mencari rezeki yang halal dan baik. Bisnis juga dapat menjadi alat mengelola bumi dengan baik dan benar jika semua aturan yang telah Allah Swt gariskan dijalankan dan diterapkan dengan baik. Bisnis juga merupakan ibadah badaniah menuju ibadah ruhiyah. Dengan bisnis, orang dapat memberikan sedekah, infaq, zakat dan lainnya sehingga dekat dengan Allah SWT. Dengan demikian, aktivitas ekonomi sebagai bagian dari muamalah yang berintikan pada upaya manusia mempertahankan kehidupan, memenuhi kebutuhan, dan meningkatkan kesejahteraannya merupakan bagian dari makna penyembahan (ibadah) dalam pengertian umum. Dalam setiap aktivitas positif, terkandung di dalamnya nilai penyembahan yang tidak hanya dalam makna khusus, seperti shalat, zakat, haji, dan lainnya.

Bisnis Proses dalam hal ini adalah sekumpulan proses yang melibatkan semua elemen dan faktor terkait dan saling bergantung dan berhubungan secara logis antara semua sumber daya di dalam organisasi Hickman, L.J (1993). Faktor-faktor terkait Bisnis Proses dalam hal ini adalah:

* Proses Operasional bisnis dari hulu sampai dengan hilir

* Peimplementasian dari Good Corporate Governance (GCG) atas operasional bank syariah

* Pelaksanaan dan pengimplementasian dari SOP/ policy/kebijakan/peraturan yang dimiliki oleh bank syariah

* Peningkatan kinerja seluruh stakeholder yang terlibat dalam perbankan syariah

* Pelaksanaan pengadaan SDM secara Syariah untuk melakukan kegiatan operasional bank syariah

* Pelaksanaan pengawasan proses pembiayaan kepada nasabah

\section{d. Perspektif Pembelajaran dan Pertumbuhan (Learning and Growth)}

Pembelajaran dan Pertumbuhan dari semua elemen/faktor terkait dan juga stakeholder yang terlibat dalam proses operasional bank syariah, dalam hal ini adalah: 
- Investasi atas proses pengembangan/training mengenai perbankan syariah baik dari segi fiqh, akad, juga proses bisnis dan pengembangannya dari SDM Syariah sebagai pelaku operasional bank syariah

* Investasi dari IT sebagai penunjang operasional sesuai dengan kebutuhan tiap divisi dalam bank syariah

* Investasi atas sistem, prosedur yang akan diberlakukan sebagai acuan kerja

* Peningkatan hubungan jama'ah antar semua stakeholder perbankan syariah

* Proses pengembangan atau inovasi dari produk-produk perbankan syariah sesuai dengan kebutuhan nasabah

- Peningkatan produktivitas karyawan dan juga pertumbuhan pelanggan

\section{Kesimpulan}

Konsep BSC dengan 4 perspektif yang di dalamnya terdiri dari; Financial (Keuangan), Customer (Pelanggan), Internal Business Process (Bisnis Proses), dan Learning \& Growth (Proses Pertumbuhan dan Pembelajaran) dapat digunakan sebagai alat ukur untuk melakukan evaluasi dan juga sebagai bentuk kontrol, yang akan meningkatkan keseluruhan proses dalam pelayanan kepada seluruh stakeholder juga kepada proses pengelolaan perbankan syariah, dan semua Stakeholder yang terkait dengan proses bisnis dari Perbankan Syariah harus juga memerhatikan segala aspek yang terkait dengan 4 perspektif tersebut agar tercapainya efektifitas dan efisiensi dari sebuah organisasi Perbankan Syariah dan meningkatnya kualitas SDM dari proses manajemen yang berjalan. 


\section{Daftar Bacaan}

Aghezzaf, E. 2005. How the BSC implementation process shapes its outcome. Journal of the Operational Research Society 56: 453-462.

Greiling, Dorothea and Johannes Kepler. 2010.Balanced scorecard implementation in German non-profit organizations. International Journal of Productivity and Performance Management Vol. 59 No. 6: 534554

Gurd, Bruce and Tian Gao. 2008. Lives in the balance: an analysis of the balanced scorecard (BSC) in healthcare organization. International Journal of Productivity and Performance Management Vol. 57 No.1: 621.

Kaplan, Robert S and David P Norton.2007. Using the Balanced Score card as a Strategic Management System. Harvard Business Review JulyAugust.

Nazir, Habib \& Hasanuddin, Muhammad, Ensiklopedi Ekonomi dan Perbankan Syariah, Bandung: Kaki Langit, 2004.

Purwanto, Andie Tri. 2003. Penerapan Balanced Scorecard Sebagai Indikator Komprehensif Pengelolaan Sumber Daya Alam - Lingkungan Hidup.

Seminar Sistem Manajemen Pengelolaan Sumber Daya Alam Lingkungan Hidup.

Salisbury, Mike; Aaron Greenberg and Maureen Simunek-Appelt 2008.

Performance Management: Focus on Performance Appraisals Office of Human Resources. Pennsylvania Banner Users Group Fall Conference.

Sinha, Abhijit. 2006. Balanced scorecard: a strategic management tool. Vidyasagar University Journal of Commerce Vol. 11.

Thakkar, JiteshS.G. Deshmukh; A.D. Gupta and Ravi Shankar. 2007.Interpretive Structural Modeling (ISM) and Analytic Network Process (ANP) Development of a balanced Scorecard an integrated approach of Indian Institute of Technology. International Journal of Productivity and Performance Management Vol. 56 No. 1: 25-59.

Yongvanich, Kittiya and James Guthrie.2009. Balanced Scorecard practices amongst Thai companies: performance effects. Australia Pacific Accounting Review Vol. 21 No. 2:132-149. 


\section{PETUNJUK PENULISAN JURNAL}

Redaksi mengundang akademisi, pakar, dan peminat bidang kajian perbankan dan ekonomi syariah atau ilmu Keislaman untuk berkonstribusi mengirimkan artikel atau karya tulisnya. Berikut petunjuk penulisannya.

Naskah ditulis dalam Bahasa Indonesia yang baik dan benar (baku).

Naskah dapat berupa hasil penelitian lapangan atau pun studi kepustakaan yang belum pernah diterbitkan pada media lainnya. Apabila pernah dipresentasikan dalam seminar atau lokakarya dan lainnya diberi keterangan yang lengkap.

Naskah diketik menggunakan program Microsoft Word (Times New Roman atau Times New Arabic untuk aksara latinnya, sedangkan tulisan arab menggunakan jenis font Traditional Arabic) dan diserahkan dalam bentuk softcopy dikirim ke j.islaminomic@yahoo.co.id

Sistematika Penulisan:

\section{a. Judul}

Judul ditulis dengan huruf besar, tebal, ukuran minimum 12 dengan posisi rata tengah

$>$ Maksimal kata dalam judul adalah 12 kata

\section{b. Nama Penulis}

Nama lengkap tanpa gelar, dipisah dengan spasi ganda dari judul. Ukuran font 10 dan rata tengah

\section{c. Abstrak}

Ditulis dengan ukuran font 10 dan dicetak miring

Maksimal 200 kata

$>$ Kata Kunci (3-5 kata)

\section{d. Isi}

Panjang naskah 15-20 halaman dengan ukuran kertas B5 (18,2 cm x 25,7 cm), meliputi;

$>$ Pendahuluan

$>$ Metode

$>$ Hasil

$>$ Pembahasan

$>$ Simpulan

\section{e. Daftar Pustaka}

Ditulis dengan format

$>$ Nama Penulis. "Judul". Nama Jurnal/Publikasi/Prosiding. Volume dan Nomor Penerbitan. Tahun.

$>$ Nama Penulis. Judul Buku. Tempat Penerbitan. Penerbit. Tahun. 